\title{
Assessment of serum interleukin-1receptor antagonist (IL-1RN) levels in overweight-obese women and its relation to the cardiovascular risk using Framingham score
}

\section{Zhian M.I. Dezayee *}

\section{Abstract}

Background and objective: Interleukin 1 receptor antagonist (IL1RN) is an acute-phase protein that blocks the interleukin-1A and 1B receptors and thereby exerting an anti-inflammatory effect. Expression and secretion of IL1R are under the influence of the metabolic derangement. This study aimed to assess the serum levels of IL1RN in obese subjects taking into consideration its relationship to the cardio-metabolic risk factors in asymptomatic obese subjects.

Methods: This cross-sectional study was conducted in Martyr LaylaQasm Center for Diabetes Mellitus in Erbil, Iraq. A total number of 170 women were recruited and distributed into three groups according to their body mass index (BMI): Group I (normal; $\leq 24.99$ $\mathrm{kg} / \mathrm{m}^{2}$ ); Group II (overweight; 25-29.99 kg/m ${ }^{2}$ ) and Group III (obese; $\geq 30 \mathrm{~kg} / \mathrm{m}^{2}$ ). The measurements of cardio-metabolic risk factors including the anthropometric measurements, blood pressure, lipid profiles and the score of cardiovascular events using Framingham Heart Study scoring were determined. Interleukin 1RN and high sensitive C-reactive protein (hs-CRP) were also determined.

Results: Overweight (Group II) and Obese (Group III) women had significant high values of cardio-metabolic risk factors. Group III have significant high values of hs-CRP, and IL IL-1RN levels compared with Group I and II. The serum levels of IL-1RN are increased as the body mass index is increased but is not associated with increased risk of the cardiovascular events or a proportional increased of hs-CRP. A significant correlation between serum IL-1RN levels with cardiovascular risk (\%) was observed among subjects of Group II.

Conclusion: The study concludes that serum IL-1RN levels are significantly increased withy body mass index in over-weight-obese subjects and its increment is not correlated with low-grade of inflammation assessed by measurement of hs-CRP. The clinical significant of determination of IL-1NR to predict cardiovascular events risk is marginal in overweight subjects.

Keywords: Interleukin1 RNR; Cardiovascular risk; Overweight-obese women.

\section{Introduction}

Interleukin-1 is a proinflammatory marker that involved with its congers in the development of metabolism disorders including the obesity. ${ }^{1,2}$ Interleukin 1 receptor antagonist (IL1RN) is an acute-phase protein that blocks the interleukin-1A and $1 \mathrm{~B}$ receptors and thereby exerting anti-inflammatory effect. ${ }^{3}$ It is produced by activated monocytes and tissue macrophages and other cells. The relationship between IL1RN, IL-1beta and metabolic derangement included that the metabolic factors, like glucose or fatty acid, stimulate the expression of the IL-1B and thereby the IL-1B stimulates the expression and secretion of the IL1RN. ${ }^{4,5}$ This substance expressed in white rather than brown adipose tissue and a high serum levels observed in obese subjects. ${ }^{6}$ A relationship between IL-1RN polymorphism encoded rs315952 and Ser133Serand obesity was observed in obese hypertensive patients. ${ }^{7}$ In one study,

* Department of Immunology, Hawler Medical University, Erbil, Iraq. 
long term inhibition of interleukin-1 by a synthetic compounds resulted in increased the risk of coronary heart disease which is linked to the increase low density lipoprotein-cholesterol (LDL-C). ${ }^{8}$ The previous study reported a non-significant association between IL-1RN gene and coronary artery disease whether single-ormultiple vessel(s) disease diagnosed by coronary angiogram. Serum levels of IL-1RN are a good marker of assessment the risk of obesity and diabetes mellitus which showed a significant inverse correlation with insulin sensitivity and positive correlation with hyperinsulinemia independent of obesity. 9,10 There is evidence that short term hyperglycemia stimulated the adipose tissue to release IL-1RN and cause significant high serum IL $-1 \mathrm{RN}$ levels. ${ }^{11}$ This study aimed to assess the serum levels of IL1RN in obese subjects taking in consideration its relationship to the cardiometabolicrisk factors in asymptomatic obese subjects.

\section{Methods}

This cross-sectional study was conducted in Martyr Layla Qasm Center for Diabetes Mellitus in Erbil, Iraq. The study was conducted according to the guidelines from the Declaration of Helsinki with approval from a local ethical review board. All patients gave written informed consent. The criteria for inclusion are overweightobese subjects with subclinical signs and symptoms of cardiometabolic derangements (hypertension, glucose intolerant and dyslipidemia) as well as the healthy subjects who had a body mass index less than $25 \mathrm{~kg} / \mathrm{m}^{2}$ and served as control. The criteria for exclusion were patients with diabetes Mellitus history of coronary artery disease, autoimmune disease, hematological, neoplastic, renal, hepatic or thyroid diseases, evidence of acute or chronic infectious disease or patients receiving treatment with anti-inflammatory drugs. Demographic data, medical history and treatment were obtained from the case-sheet data in the center. Modifiable risk factors, events or complications, and current therapy were recorded. A person who reported smoking on admission was defined as a current smoker. The following anthropometric measurements are determined: height $(\mathrm{m})$, weight $(\mathrm{kg})$, waist circumference $(\mathrm{cm})$. The body mass index and waist/height ratios were calculated taking the cut-off level of waist to height ratio $\geq 0.5$ as an indication of cardiovascular risk. The blood pressure $(\mathrm{mmHg})$ was measured on sitting position and the mean of three readings was taken. Peripheral venous blood was drawn immediately after admission into tubes. Then, the samples were centrifuged at $2500 \mathrm{rpm}$ for $10 \mathrm{~min}$, and the sera were separated for determination of high sensitivity C-reactive protein, fasting lipid profile (including total cholesterol (TC), triglycerides (TG) and high density lipoprotein-cholesterol (HDL-C) and IL1RN. Quantitative determination of serum hs-CRP and IL1RN were determined using the enzyme linked immunosorbent assay (ELISA) technique. The following values of hs-CRP indicated the levels of cardiovascular event risk: $<1.0 \mathrm{mg} / \mathrm{L}$ (low risk), $1.0-3.0 \mathrm{mg} / \mathrm{L}$ (Intermediate risk) and $>3.0 \mathrm{mg} / \mathrm{L}$ (high risk). The risk of cardiovascular events was assessed by calculating the scores of the Framingham Heart Study. ${ }^{12}$ The patients were grouped according to the body mass index into:

Group I: subjects with BMI $18-24.99 \mathrm{~kg} / \mathrm{m}^{2}$ represented the control group

Group II: subjects with BMl 25-29.99 kg/m² represented the overweight group

Group III: subjects with BMI $\geq 30 \mathrm{~kg} / \mathrm{m}^{2}$ represented the obese group

\section{Statistical analysis}

Data are expressed as number, percent, mean \pm SD. One way ANOVA and difference between percentage tests were applied to evaluate differences between groups and the simple correlation test was applied for the association between the independent and dependent factors. A $P$ value of $\leq 0.05$ was considered statistically significant. All calculations were 
made using the statistical package for the social sciences (version 20) Program for Windows.

\section{Results}

Table 1 shows the determinants of cardio-metabolic risk of the subjects enrolled in the study. The mean age value of Group III was significantly higher than corresponding values of Group I and II. The number of smokers among Group I was significantly higher than corresponding numbers among Group II and III. According to the criteria of inclusion, the BMI of Group III was significantly higher than Group I and II and was significantly higher in Group II compared with Group I. Waist circumference levels attended significant higher value among Group I and II. The waist-height ratio of Group III exceeded the significant cut-off value of 0.5 and was significantly higher than corresponding levels of Group I and II. The waist-height ratio of overweight subjects (Group II) did not exceed the cut-off level, but were significantly higher than corresponding value of Group I. Table 1 shows that the systolic blood pressure was significantly higher in Group II and III subjects compared with Group I. Whereas, the diastolic blood pressure was significantly higher than corresponding values of Group I and II subjects. The levels of serum lipid profiles of Group II and III subjects are significantly higher than corresponding values of Group I and a non-significant difference observed between Group II and III.

Table 1: Determinants of cardiovascular risk among overweight-obese women compared with non-obese women

\begin{tabular}{lccc}
\hline Determinants & $\begin{array}{c}\text { Group I } \\
(\mathbf{n = 3 0 )}\end{array}$ & $\begin{array}{c}\text { Group II } \\
(\mathbf{n}=\mathbf{7 0})\end{array}$ & $\begin{array}{c}\text { Group III } \\
(\mathbf{n}=70)\end{array}$ \\
\hline Age (Year) & $55.0 \pm 3.8$ & $63.6 \pm 3.3^{*}$ & $65.1 \pm 4.4^{*} \dagger \dagger$ \\
Smoking & $19(63.3)$ & $26(37.1)^{*}$ & $26(37.1)^{*}$ \\
& & & \\
Body mass index $\left(\mathrm{kg} / \mathrm{m}^{2}\right)$ & $23.72 \pm 0.63$ & $29.30 \pm 0.45^{*}$ & $35.2 \pm 0.9^{*} \dagger$ \\
Waist circumference $(\mathrm{cm})$ & $79.3 \pm 1.7$ & $80.4 \pm 2.1^{* *}$ & $98.2 \pm 3.6^{*} \dagger$ \\
Waist/height ratio & $0.469 \pm 0.01$ & $0.484 \pm 0.01^{*}$ & $0.587 \pm 0.02^{*} \dagger$ \\
& & & \\
Blood pressure (mm Hg) & & & \\
Systolic & $117.7 \pm 2.1$ & $141.5 \pm 4.1^{*}$ & $140.6 \pm 3.6^{*}$ \\
Diastolic & $77.2 \pm 2.5$ & $86.9 \pm 3.7^{*}$ & $90.1 \pm 3.3^{*} \dagger$ \\
& & & \\
Fasting serum lipid profile levels (mg/dl) & & & \\
$\quad$ Total cholesterol & $180.7 \pm 8.2$ & $314.1 \pm 25.0^{*}$ & $321.6 \pm 30.2^{*}$ \\
Triglycerides & $136.5 \pm 5.4$ & $349.3 \pm 35.8^{*}$ & $357.8 \pm 38.4^{*}$ \\
High density lipoprotein-cholesterol & $53.7 \pm 4.9$ & $36.9 \pm 2.3^{*}$ & $35.4 \pm 2.4^{*}$ \\
& & & \\
\hline
\end{tabular}

The results expressed as number (\%) and mean \pm SD. ${ }^{*} P<0.001,{ }^{* *} P<0.001$ compared with Group I; $† P<0.001$, $† \uparrow P<0.05$ compared with Group II. 
Table 2 shows significant high levels of hs-CRP among Group III subjects compared with Group I and II. The serum IL-1RN levels amounted significant higher levels among Group II and III compared with Group I and II respectively. The cardiovascular event risk attended significant high percent in Group II and III compared with Group I and the difference of the cardiovascular risk percent between overweight (Group II) and obese women (Group III) reached 2.5\%. The serum levels of IL-1RN are increased as the body mass index is increased.Significant correlations between serum IL-RN levels with BMI observed among subjects of Group II and III (Table 3).Significant correlations between serum IL-RN levels with waist-height ratio observed among subjects of Group I and III (Table 3). Non-significant correlations between serum IL-RN levels with serum hs-CRP levels observed among subjects of Group I, II and III (Table 3).Significant correlations between serum IL-RN levels with cardiovascular risk (\%) observed among subjects of Group II (Table 3).

\section{Discussion}

The results of this study show that obese subjects have significantly high levels of hs-CRP and IL-1RN compared with non-obese and overweight subjects. The serum levels of IL-1RN are correlated with $\mathrm{BMI}$ and waist to height ratio but did not correlate with serum hs-CRP levels or cardiovascular risk (\%) in obese subjects. Interleukin-1RN is included in the IL-1 family which played a role in the regulation of energy homeostasis and contributed in cellular metabolism. ${ }^{1,2}$ (IL-1RN) involved in the regulation of the adipogenesis and high serum levels of IL-1RN was reported in obese subjects as demonstrated in this study. ${ }^{6}$ The significant high levels of IL-1RN in Group III compared with Group II may be linked to the polymorphism of IL-1RN gene as IL-1RN*2 carriers had increased total fat and serum levels of IL-1RN andIL-1RN. The other possible explanation is IL-1RN production is increased in obese subjects to suppress the activity of $\mathrm{IL}-1 .^{13}$ The production of C- reactive protein (CRP) is regulated by a number of cytokines including IL-RN there

Table 2: Serum levels of high sensitivity C-reactive protein and interleukin-1RN in respect the cardiovascular risk (\%) assessed by Framingham Heart Study scoring.

\begin{tabular}{lccc}
\hline Determinants & Group I & Group II & Group III \\
\hline High sensitivity C-reactive protein $(\mathrm{mg} / \mathrm{L})$ & $3.9 \pm 0.2$ & $4.0 \pm 0.5$ & $4.5 \pm 0.6^{*} \dagger$ \\
Interleukin-1RN $(\mathrm{ng} / \mathrm{ml})$ & $357.1 \pm 50.1$ & $656.2 \pm 70.4^{*}$ & $879.4 \pm 33.8^{*} \dagger$ \\
Cardiovascular risk $(\%)$ & $5.76 \pm 1.7$ & $26.0 \pm 7.2^{*}$ & $28.5 \pm 9.2^{*}$ \\
\hline
\end{tabular}

The results expressed as mean \pm SD. ${ }^{*} P<0.001$ compared with Group I; $\dagger P<0.001$ compared with Group II.

Table 3: Correlation of serum interleukin-1RN levels with the determinants that related to cardiometabolic risk.

\begin{tabular}{lccc}
\hline Determinants & Group I & Group II & Group III \\
\hline Body mass index $\left(\mathrm{kg} / \mathrm{m}^{2}\right)$ & 0.348 & $0.450^{* *}$ & $0.379^{* *}$ \\
Waist to height ratio & $0.390^{*}$ & 0.186 & $0.482^{* *}$ \\
High sensitivity C-reactive protein $(\mathrm{mg} / \mathrm{L})$ & 0.136 & 0.228 & 0.002 \\
Cardiovascular risk (\%) & 0.195 & $0.267^{*}$ & -0.026 \\
\hline
\end{tabular}

The results expressed as correlation factor $(r) .{ }^{*} P<0.05,{ }^{* *} P<0.001$ 
are no significant correlations between CRP and IL-1RN as this study confirmed the other studies. ${ }^{14}$ The relation between the cardiovascular risk and IL-RN levels is observed in overweight but not in obese subjects. Previous studies demonstrated that there is an association between the genotype of c/c IL-1RN and restenosis of the coronary artery after implantation bare metal stent, that is, a stent with an anti-inflammatory drug eluting stent. ${ }^{15}$ Moreover, Fragoso et al. ${ }^{16}$ found that subjects who have polymorphism of IL-1RN6/2 gene are at risk of developing the acute coronary syndrome. This study shows that the risk of cardiovascular events is correlated with serum levels of IL$1 \mathrm{RN}$ in overweight subjects. This indicates that determination of IL-1RN levels in overweight subjects with dyslipidemia could predict the risk of developing coronary artery disease. Dyslipidemia is a risk factor for coronary artery disease and is reported in this study among over-weight and obese subjects and it is unlikely to bias the correlation between the serum levels of IL$1 \mathrm{RN}$ and the cardiovascular risk because there is no relationship between the lipoprotein-1 and IL-1RN levels as demonstrated by $\mathrm{Xu}$ et al. ${ }^{17}$ One of the limitations of the study is that overweightobese subjects have dyslipidemia which may influence the obtained results.

\section{Conclusion}

Serum IL-1RN levels are significantly increased withy body mass index in over-weight-obese subjects and its increment is not correlated with low-grade of inflammation assessed by measurement of hs-CRP. The clinical significant of determination of IL-1NR to predict cardiovascular events risk is marginal in overweight subjects.

\section{Conflicts of interest}

The author reports no conflicts of interest.

\section{References}

1. Erion JR, Wosiski-Kuhn M, Dey A, Hao S, Davis CL, Pollock NK, et al. Obesity elicits interleukin 1-mediated deficits in hippocampal synaptic plasticity. J Neurosci 2014; 34(7): 2618-31.

2. Khalkhal A, Haddar A, Semiane N, Mallek A, Abdelmalek A, Castex $F$, et al. Obesity, insulin resistance and diabetes in the sand rat exposed to a hypercaloric diet; possible protective effect for IL1-beta. C R Biol 2012; 335(4):271-8.

3. Juge-Aubry CE, Meier CA. Immunomodulatory actions of leptin. Mol Cell Endocrinol 2002; 194 $(1-2): 1-7$

4. Dasu MR, Devaraj S, Jialal I. High glucose induces IL-1beta expression in human monocytes: mechanistic insights. Am J Physiol Endocrinol Metab 2007; 293(1):E337-46

5. Böni-Schnetzler M, Boller S, Debray S, Bouzakri K, Meier DT, Prazak R, e al. Free fatty acids induce a proinflammatory response in islets via the abundantly expressedinterleukin-1 receptor I. Endocrinology 2009; 150(12):5218-29.

6. Somm E, Henrichot E, Pernin A, Juge-Aubry CE, Muzzin P, Dayer JM, et al. Decreased fat mass in interleukin-1 receptor antagonist-deficient mice: impact on adipogenesis, food intake, and energy expenditure. Diabetes 2005; 54(12):3503-9.

7. Yang SA. Exonic polymorphism (rs315952, Ser133Ser) of interleukin 1 receptor antagonist (IL1RN) is related to overweigh/obese with hypertension. J Exerc Rehabil 2014; 10(5):332--6.

8. Interleukin 1 Genetics Consortium. Cardiometabolic effects of genetic upregulation of the interleukin 1 receptor antagonist: a Mendelianrandomisation analysis. Lancet Diabetes Endocrinol 2015; 3(4):243-53

9. Saltevo J, Laakso M, Jokelainen J, Keinänen-Kiukaanniemi S, Kumpusalo E, Vanhala M. Levels of adiponectin, C-reactive protein and interleukin-1 receptor antagonist are associated with insulin sensitivity: a population-based study. Diabetes Metab Res Rev 2008; 24(5):378-83.

10. Bissonnette S, Saint-Pierre N, Lamantia V, Cyr $Y$, Wassef $H$, Faraj M. Plasma IL-1Ra: linking hyperapoB to risk factors for type 2 diabetes independent of obesity in humans. Nutr Diabetes 2015; 5:e180.

11. Siklova M, Simonsen L, Polak J, Stich V, Bülow $\mathrm{J}$. Effect of short-term hyperglycemia on adipose tissue fluxes of selected cytokines in vivo during multiple phases of diet-induced weight loss in obese women. J Clin Endocrinol Metab 2015; 100 (5):1949-56.

12. D'Agostino RB Sr, Vasan RS, Pencina MJ, Wolf PA, Cobain M, Massaro JM, et al. General cardiovascular risk profile for use in primary care: the Framingham Heart Study. Circulation 2008; 117(6):743-53.

13. Andersson N, Strandberg L, Nilsson S, Ljungren $\mathrm{O}$, Karlsson MK, Mellström D, et al. Variants of the interleukin-1 receptor antagonist gene are associated with fat mass in men. Int $\mathrm{J}$ Obes (Lond) 2009; 33(5):525-33. 
14. Latkovskis G, Licis N, Kalnins U. C-reactive protein levels and common polymorphisms of the interleukin-1 gene cluster and interleukin- 6 gene in patients with coronary heart disease. Eur $\mathrm{J}$ Immunogenet 2004; 31(5):207-13.

15. Hoppmann P, Koch W, Laugwitz KL, Kastrati A. Genetic risk of restenosis after percutaneous coronary interventions in the era of drug-eluting stents. Coronary Artery Dis 2014; 25 (8):658-64.

16. Fragoso JM, Delgadillo $H$, Llorente L, Chuquiure $\mathrm{E}$, Juárez-Cedillo $\mathrm{T}$, Vallejo $\mathrm{M}$, et al. Interleukin 1 receptor antagonist polymorphisms are associated with the risk of developing acute coronary syndrome in Mexicans. Immunol Lett 2010; 133 (2):106-11.

17. $\mathrm{Xu} \mathrm{P}, \mathrm{Li} \mathrm{Y}$, Zhang PA, Li XY, Li GS. The distribution of gene polymorphisms in the intron 2 and exon 2 of interleukin1 receptor antagonist and their correlation with the serum lipoprotein level. Zhonghua Liu Xing Bing Xue Za Zhi 2004; 25(6):522-6. 